Article

\title{
Wheat Nitrogen Fertilisation Effects on the Performance of the Cereal Aphid Metopolophium dirhodum
}

\begin{abstract}
Alan F. J. Gash
Department of Agricultural Sciences, P.O. Box 84, Lincoln University 7647, Christchurch, New Zealand; E-Mail: alan.gash@lincoln.ac.nz; Tel.: +64-3-325-3838 ext. 8653

Received: 14 December 2011; in revised form: 16 January 2012 / Accepted: 1 February 2012 / Published: 9 February 2012

Abstract: The effects of five rates of nitrogen fertiliser applications on the performance of the cereal aphid Metopolophium dirhodum on winter wheat, within the range of rates recommended for UK crops, were investigated over two seasons in field-grown crops and also on plants grown in the glasshouse. Longevity was unaffected by the level of fertilisation, but aphid intrinsic rate of increase and fecundity increased with each level applied. In the second field season, when a higher upper limit was used, many of these increases were significant. A previously unreported finding for this species was that there was a significant decrease in fecundity for the highest rate of fertilisation. Results for the glasshouse-reared aphids followed a similar pattern to those in the field, and overall they underline recent reports in the literature of the negative effects of high nutrient concentrations on the performance of herbivorous insects. The underlying reasons for these are discussed.
\end{abstract}

Keywords: intrinsic rate of increase; fecundity; phloem sap; plant quality; winter wheat

\section{Introduction}

Aphids occur throughout the world [1,2], with over forty species associated with Gramineae in Europe [3,4]. The rose-grain aphid Metopolophium dirhodum (wlk.), along with the cereal aphid Sitobion avenae (f.), are two of the species most frequently found in most European countries [5-8] and both are generally regarded as the most serious pests in cereals in England in the spring and summer [9]. M. dirhodum is almost entirely a leaf feeder [4,7] and can reproduce parthenogenetically and viviparously to develop large populations in a short space of time [10,11]. In the United Kingdom M. dirhodum usually overwinters in the egg stage on rose (Rosa) species [12]. The eggs hatch at budburst in early spring and, following two or three generations on rose, alate (winged) aphids migrate 
to numerous species of grasses and cereals from late spring onwards [9]. They initially feed on the lowest of the green leaves and as these leaves senesce they move up the plant to occupy higher leaves, feeding eventually on the flag leaf [13]. Populations tend to decline approximately at the crop's milky ripe stage of grain development [14,15] (growth stage 73-77 on Zadok's [16] scale).

Fertilisation with nitrogen $(\mathrm{N})$ is routinely applied to crops to increase their yield and food quality; recommendations for winter wheat in the UK rise to $250 \mathrm{~kg} \mathrm{~N} /$ ha for the majority of soils (the upper limit is $280 \mathrm{~kg} \mathrm{~N} /$ ha for shallow soils with no residual reserves of $\mathrm{N}$ ) depending on yield potential [17]. Plants supplied with optimum levels are able to retain photosynthetically active leaves for longer due to delayed senescence compared to leaves of plants supplied with deficient levels of $\mathrm{N}$ levels that senesce earlier. Consequently, $\mathrm{N}$ deficient plants have reduced growth leading to reduced yield and yield quality [18]. In cereals $\mathrm{N}$ promotes stem extension, encourages tiller survival and leaf area development, increases the number of shoots per plant and improves grain yield and protein content [19-21]. When $\mathrm{N}$ applied to crops is absorbed and assimilated, it is involved in the synthesis of amino acids required for growth [22]. The transport of amino acids, together with the products of photosynthesis, especially sucrose, takes place in the phloem [23].

Most species of aphid feed in the sieve elements of the phloem tubes [24-26] and the phloem performs several important functions for the plant, particularly the transportation of photosynthates from source organs (such as mature leaves) to sink organs such as the developing cereal grain [22]. The phloem also transports a range of macromolecules, such as proteins or RNAs, which may act as signals in response to developmental or stress triggers [27]. Aphids penetrate the sieve elements with their stylet mouthparts and high hydrostatic pressure within the elements causes phloem sap to exude out into the stylets [24]. The main components of phloem sap are sugars and amino acids [23]. However, their composition can vary between plant species [28], stages of plant development [29], abiotic factors such as temperature, nitrogen and water availability [30], and biotic stress such as aphid feeding [31]. There may also be diurnal variations in phloem sap composition [32] and, probably as a result of structural differences, variation in the composition of individual sieve tube elements [33]. Aphids, similar to other herbivorous insects, require sugars, nitrogenous compounds (amino acids) and other nutrients from their diet [34] and they ingest these from the phloem. Also, within the gut of aphids are bacterial symbionts [35] which can upgrade dietary nonessential amino acids to essential amino acids [36,37] when there are sufficient quantities of non-essential amino acids available for this; they can also synthesise essential amino acids [38].

The way in which plant nitrogen fertilisation affects aphids in general, and cereal aphids in particular, is unclear. The results of studies into the abundance of cereal aphids in the 1990's, which were primarily concerned with economic effects on crops and followed a number of outbreaks attributed to increased $\mathrm{N}$ inputs, were ambiguous. Two field-based studies into the abundance of $M$. dirhodum and S. avenae on winter wheat [19,39] using five rates of nitrogen fertilisation (from 0 to $160 \mathrm{~kg} \mathrm{~N} / \mathrm{ha}$ and from 50 to $250 \mathrm{~kg} \mathrm{~N} / \mathrm{ha}$, respectively) concluded that natural populations of $M$. dirhodum increased with nitrogen input, but that $S$. avenae was little affected. Another field-based study [40] using three rates of nitrogen $(0,190$ and a 130-220 kg N/ha canopy management rate) also found that $M$. dirhodum increased with nitrogen input, but that higher populations of $S$. avenae were found in plots which had received nitrogen in some years, but in the no $\mathrm{N}$ plots in other years. 
These field-based studies relied on infestations of natural aphid populations, but more recent work has concentrated on specific aspects of aphid and plant physiology. Much of this work has been conducted in controlled environment situations and has highlighted the complexity of the relationship between aphids and plant nitrogen, which is now considered to be a more complex one than a simple correlation with the $\mathrm{N}$ content of the insects' diet [41]. Techniques seeking to establish a closer link with sap components, plant nutrients and aphid performance have included the use of aphid stylectomy and electrical penetration graphs (EPG) to monitor aphid feeding. These studies, with different aphid species, have included the effects of aphid performance on hydroponically grown barley seedlings with no nutrient levels versus a high $(8 \mathrm{mM}) \mathrm{N}$ solution [30], and on developmentally young potato plants with 'nutrient rich' phloem versus mature 'poor' phloem plants [29]; another study with aphids on milkweed used a narrow range of rates $\left(0,5\right.$ and $\left.10 \mathrm{~g} \mathrm{~N} / \mathrm{m}^{2}\right)$ [42].

Very few recent studies have investigated effects for a wide range of nitrogen rates [43], at levels commonly used in practice in the field and few publications have considered fecundity directly [44]. The aims of this study therefore were to investigate the effects of applied $\mathrm{N}$ on the longevity, intrinsic rate of increase and fecundity of $M$. dirhodum on winter wheat in the field (along with a complementary glasshouse study) and to ascertain whether any such effects could be found within a wider range of applied levels of nutrient than have previously been used, and with rates equivalent to those commonly applied to UK crops.

\section{Materials and Methods}

Experiments were carried out over two years in different fields on field-grown winter wheat (Triticum aestivum L.) (cv Riband) and also on glasshouse-grown plants. The experiments consisted of assessing the performance of individual adult apterae (wingless aphids) installed in clip cages on the flag leaves of plants.

\subsection{Aphids}

Individual adult apterae from a culture of aphids which had been maintained over several months on Riband wheat plants grown in well watered compost, were transferred to excised Riband leaves in rearing units [45] to begin nymph production. When not more than eight hours old, individual nymphs were removed from the rearing units using a fine hair brush and placed in a clip cage on the main stem flag leaf of wheat plants, either in the field (see Section 2.2) or in the glasshouse (see Section 2.3). The basic design of the cages was as described by Noble [46], but modified in that the acrylic tubing used had an internal diameter of $20 \mathrm{~mm}$ and the aphid-proof netting was glued directly to the tubing. Also, to reduce the overall cage weight, instead of an acrylic ring attached to the lower prong of the hair-curl clip, this was heated and inserted into a $35 \mathrm{~mm} \times 35 \mathrm{~mm}$ piece of $4 \mathrm{~mm}$ thick polystyrene; the upper prong was bent and glued to the side of the tubing. Once caged, aphids found not to have survived the first 24 hours (only) were replaced with another of the same age; thereafter they were left for the duration of the experiment.

The experiments were monitored daily and the dates when aphids reached adulthood, initiated reproduction and died were recorded, and any offspring produced were counted and removed. Performance was assessed by comparing longevity, fecundity and estimated intrinsic rate of increase 
$\left(r_{m}\right)$. Fecundity was quantified as (total number of offspring/adult lifespan in days) and $r_{m}$ was calculated as $0.738(\ln N) / T_{\mathrm{d}}$, where $N$ is the number of offspring produced by an aphid in the time period equivalent to the pre-reproductive development period $\left(T_{\mathrm{d}}\right)$ [47].

\subsection{Field Plots}

Field plots were located in a commercial second year winter wheat crop in Essex UK, grown according to usual farm practice. This included pre-sowing measures to ensure the soil was at a suitable $\mathrm{pH}$ and that it contained adequate nutrient levels (including $\mathrm{P}$ and $\mathrm{K}$ ) required by wheat, as described by the UK Fertiliser Manual [17]. The crops were drilled with a conventional seed drill in October each year and received applications of herbicide and a plant growth regulator the following spring. Also at this time, prior to the start of aphid migrations, an aphicide was applied to eliminate insects which may have colonised in the autumn, but no further insecticides were used. However, two applications of fungicide were applied in May and June each year.

The plots $(12 \mathrm{~m} \times 12 \mathrm{~m})$ were laid out in a randomised block design of five nitrogen treatments (one per plot) in each of four blocks, giving a total of 20 plots. The plots received varying levels of a $34.5 \%$ $\mathrm{NH}_{4} \mathrm{NO}_{3}$ fertiliser applied at Zadok's [48] growth stage (GS) 30/31. In the first year fertiliser rates of $75,100,125,150$ and $175 \mathrm{~kg} \mathrm{~N} /$ ha were used and in year two the rates were 50, 100, 150, 200 and $250 \mathrm{~kg} \mathrm{~N} / \mathrm{ha}$.

Aphid cages (each with one nymph) were installed during early anthesis (GS 60 to 64) - seven or eight on randomly selected plants (one cage per plant) in each plot; this was to ensure that at least five nymphs survived to complete the field experiment.

Harvesting was undertaken by hand by cutting four $\times 1 \mathrm{~m}^{2}$ samples from each plot when the grain was ripe (GS 91/92). Grain was separated from the ears using a static threshing machine.

\subsection{Glasshouse Plants}

Wheat seeds were sown individually in potting compost (Levingtons M2) in deep cell (25 $\mathrm{mm} \times 80 \mathrm{~mm}$ ) plug trays. They were vernalised for eight weeks after emergence by being held at $4{ }^{\circ} \mathrm{C}$ with $85 \% \mathrm{RH}$ and an L8:D16 lighting regime. Plants with their root balls attached were transferred to vertical sided $(150 \mathrm{~mm}$ diameter $\times 250 \mathrm{~mm})$ pots with saucers in the glasshouse. The pots were filled with inert Rockwool fibre from which sections, of a sufficient size to just receive the root-balled plants, had been removed. Five plants were transferred to each pot to give a similar plant density $\left(250 / \mathrm{m}^{2}\right)$ to those grown under field conditions. Six pots (30 plants in total) were used for each of five nitrogen treatments. Plants were initially with a nitrogen-free nutrient solution as described by Hewitt [49], which was applied to the pot surface until it just flowed into the saucer. Each pot and saucer was moved daily to a randomly determined bench position to eliminate any effects that glasshouse position may have had on aphid performance. At GS 31 pots were watered with a solution containing only $\mathrm{NH}_{4} \mathrm{NO}_{3}$ in $250 \mathrm{~mL}$ distilled water, mixed to provide fertiliser amounts equivalent to field rates of 0 , $60,120,180$ and $240 \mathrm{~kg} \mathrm{~N} / \mathrm{ha}$. Two weeks after the plants were installed in the glasshouse they were treated with a fungicide spray to protect against powdery mildew (Erysiphe graminis); this was repeated two weeks before aphids were caged on the plants. Glasshouse temperature was maintained at $16(+/-4){ }^{\circ} \mathrm{C}$ and natural light levels were supplemented with artificial lights (Grolux fluorescent 
tubes), initially for eight hours; this was gradually increased to a L16:D8 lighting programme by the time the aphids were caged on the plants.

Aphid cages were installed at GS 59; five cages per pot (one per plant) were used, giving a total of 30 per treatment. When the experiment ended (approximately 40 days after the aphids were installed), all the above-ground plant tissue from each pot was removed for nitrogen analysis.

\subsection{Nitrogen Analysis}

A sub-sample of harvested grain from the field plots and the above-ground plant material from the glasshouse plants was subjected to nitrogen analysis using the Kjeldahl method [50].

\subsection{Data Analysis}

Data were subjected to ANOVA with SPSS for Windows, Release 6.0. ANOVA was carried out on aphid development and reproductive capacity using the mean values per glasshouse pot (giving 6 replicates $\times 5 \mathrm{~N}$ rates), or field plot (giving 4 replicates $\times 5 \mathrm{~N}$ rates); analysis of the field results was done separately for each year. ANOVA was also carried out on the angular transformation $\left(\sin ^{-1}(\sqrt{ } \mathrm{x})\right)$ of the percentage of nitrogen contained in the grain or whole plants. Tukey's (HSD) Test [51] at $\alpha=0.5$ was used to distinguish the mean differences which were significant.

\section{Results}

In the following text, for the results from the glasshouse experiment there are 4,25 degrees of freedom and for those from the field experiments there are 4,12 degrees of freedom.

\subsection{Longevity}

There was no apparent effect on aphid longevity for any of the experiments (field trial year one $\mathrm{F}=1.84, P=0.235$; field trial year two $\mathrm{F}=0.21, P=0.913$; glasshouse $\mathrm{F}=2.60, P=0.090$ ). Mean longevity in the field across all treatments was 29.0 days and 26.7 days in field trial years one (Table 1) and two (Table 2) respectively; mean glasshouse longevity was 35.6 days (Table 3 ). 
Table 1. Effects of five rates of nitrogen fertiliser applications to winter wheat in the field on the performance of Metopolophium dirhodum and on the nitrogen content of the harvested grain in year one. Values are means $( \pm$ S.E. $)$ from four replicates. Letters above components indicate when significant differences were found; those with the same letter are not significantly different at the $5 \%$ level.

\begin{tabular}{|l|ccccc|}
\hline \multirow{2}{*}{$\begin{array}{l}\text { Performance } \\
\text { measure }\end{array}$} & \multicolumn{5}{|c|}{ Fertiliser applied (kg N/ha) } \\
\hline Longevity (days) & $\mathbf{7 5}$ & $\mathbf{1 0 0}$ & $\mathbf{1 2 5}$ & $\mathbf{1 5 0}$ & $\mathbf{1 7 5}$ \\
& 28.4 & 27.9 & 29.7 & 30.0 & 28.9 \\
& $(0.35)$ & $(0.23)$ & $(0.35)$ & $(0.42)$ & $(0.22)$ \\
\hline Fecundity & 1.9 & 2.1 & 2.2 & 2.3 & 2.4 \\
(nymphs/day) & $(0.12)$ & $(0.15)$ & $(0.09)$ & $(0.12)$ & $(0.13)$ \\
\hline Intrinsic rate & 0.169 & 0.175 & 0.177 & 0.181 & 0.184 \\
of increase $\left(\boldsymbol{r}_{\boldsymbol{m}}\right)$ & $(0.004)$ & $(0.004)$ & $(0.003)$ & $(0.003)$ & $(0.003)$ \\
\hline & $\mathbf{a}$ & $\mathbf{a b}$ & $\mathbf{a b}$ & $\mathbf{b c}$ & $\mathbf{c}$ \\
\% Grain $\mathbf{N}$ & 1.36 & 1.46 & 1.52 & 1.68 & 1.78 \\
& $(0.01)$ & $(0.04)$ & $(0.04)$ & $(0.01)$ & $(0.01)$ \\
\hline
\end{tabular}

Table 2. Effects of five rates of nitrogen fertiliser applications to winter wheat in the field on the performance of Metopolophium dirhodum and on the nitrogen content of the harvested grain in year two. Values are means ( \pm S.E.) from four replicates. Letters above components indicate when significant differences were found; those with the same letter are not significantly different at the $5 \%$ level.

\begin{tabular}{|l|ccccc|}
\hline & \multicolumn{5}{|c|}{ Fertiliser applied (kg N/ha) } \\
$\begin{array}{l}\text { Performance } \\
\text { measure }\end{array}$ & $\mathbf{5 0}$ & $\mathbf{1 0 0}$ & $\mathbf{1 5 0}$ & $\mathbf{2 0 0}$ & $\mathbf{2 5 0}$ \\
\hline & & & & & \\
Longevity (days) & 27.0 & 26.2 & 27.6 & 26.6 & 26.0 \\
& $(0.29)$ & $(0.72)$ & $(0.57)$ & $(0.61)$ & $(0.60)$ \\
\hline & $\mathbf{a}$ & $\mathbf{a b}$ & $\mathbf{a b}$ & $\mathbf{b}$ & $\mathbf{a c}$ \\
Fecundity & 2.1 & 2.7 & 3.0 & 3.1 & 2.2 \\
(nymphs/day) & $(0.18)$ & $(0.17)$ & $(0.21)$ & $(0.21)$ & $(0.20)$ \\
\hline $\begin{array}{l}\text { Intrinsic rate } \\
\text { of increase }\left(\boldsymbol{r}_{\boldsymbol{m}}\right)\end{array}$ & 0.191 & 0.215 & 0.216 & 0.217 & 0.189 \\
& $(0.006)$ & $(0.005)$ & $(0.005)$ & $(0.004)$ & $(0.009)$ \\
\hline & $\mathbf{a}$ & $\mathbf{b}$ & $\mathbf{b}$ & $\mathbf{c}$ & $\mathbf{c}$ \\
& 1.35 & 1.72 & 1.89 & 2.14 & 2.30 \\
& & & & & \\
& $(0.04)$ & $(0.01)$ & $(0.01)$ & $(0.02)$ & $(0.04)$ \\
\hline
\end{tabular}


Table 3. Effects of five rates of nitrogen fertiliser applications to winter wheat plants grown in the glasshouse on the performance of Metopolophium dirhodum and on the nitrogen content of the harvested plants. Values are means $( \pm$ S.E. $)$ from six replicates. Letters above components indicate when significant differences were found; those with the same letter are not significantly different at the $5 \%$ level.

\begin{tabular}{|l|ccccc|}
\hline & \multicolumn{5}{|c|}{ Fertiliser applied (kg N/ha equivalent) } \\
measure & $\mathbf{0}$ & $\mathbf{6 0}$ & $\mathbf{1 2 0}$ & $\mathbf{1 8 0}$ & $\mathbf{2 4 0}$ \\
\hline Longevity (days) & 38.0 & 35.6 & 38.1 & 33.4 & 33.1 \\
& $(0.88)$ & $(0.81)$ & $(0.88)$ & $(0.69)$ & $(0.77)$ \\
\hline & $\mathbf{a}$ & $\mathbf{a b}$ & $\mathbf{a b}$ & $\mathbf{b}$ & $\mathbf{b}$ \\
Fecundity & 2.4 & 2.5 & 2.7 & 3.1 & 2.9 \\
(nymphs/day) & $(0.16)$ & $(0.12)$ & $(0.13)$ & $(0.15)$ & $(0.14)$ \\
\hline & $\mathbf{a}$ & $\mathbf{a b}$ & $\mathbf{a b}$ & $\mathbf{b}$ & $\mathbf{b}$ \\
Intrinsic rate & 0.179 & 0.187 & 0.192 & 0.203 & 0.197 \\
of increase $\left(\boldsymbol{r}_{\boldsymbol{m}}\right)$ & $(0.005)$ & $(0.003)$ & $(0.004)$ & $(0.005)$ & $(0.006)$ \\
\hline Whole plant & $\mathbf{a}$ & $\mathbf{b}$ & $\mathbf{b c}$ & $\mathbf{c d}$ & $\mathbf{d}$ \\
& & & & & \\
N content (\%) & 0.81 & 1.00 & 1.16 & 1.26 & 1.44 \\
& $(0.02)$ & $(0.03)$ & $(0.04)$ & $(0.04)$ & $(0.06)$ \\
\hline
\end{tabular}

\subsection{Fecundity}

In field trial year one, every increase in applied fertiliser led to an increase in aphid fecundity from 1.9 to 2.4 nymphs per day (Table 1$)$, but none of these increases were significant $(\mathrm{F}=2.43, P=0.105)$. In field trial year two (Table 2), increases in applied fertiliser led to increases in aphid fecundity for the first four rates (50 to $200 \mathrm{~kg} \mathrm{~N} / \mathrm{ha}$ ), from 2.1 to 3.1 nymphs per day, but there was a decrease in fecundity to 2.2 nymphs per day for the highest $(250 \mathrm{~kg} \mathrm{~N} / \mathrm{ha})$ rate used. Differences were significant (F $=3.88 ; P<0.05)$ between the $50 \mathrm{~kg} \mathrm{~N} / \mathrm{ha}$ and $200 \mathrm{~kg} \mathrm{~N} / \mathrm{ha}$ fertiliser rates; the observed decrease in fecundity between the 200 and $250 \mathrm{~kg} \mathrm{~N} /$ ha rates was also significant. A similar trend of increases in fecundity for the first four fertiliser rates (0 to $180 \mathrm{~kg} \mathrm{~N} / \mathrm{ha}$ ) of 2.4 to 3.1 nymphs per day and a decrease to 2.9 nymphs per day for the highest $(240 \mathrm{~kg} \mathrm{~N} / \mathrm{ha})$ rate occurred with the glasshouse experiment (Table 3). However, although the differences between the 0 nitrogen rate and the two highest rates (180 and $240 \mathrm{~kg} \mathrm{~N} / \mathrm{ha})$ were significant $(\mathrm{F}=5.69 ; P<0.01)$, the observed decrease in fecundity between the two highest rates was not significant.

\subsection{Intrinsic Rate of Increase}

In a similar manner to the results for fecundity, in field trial year one $r_{m}$ increased with every increase in fertiliser applied (Table 1) from 0.169 to 0.184 , but none of these increases were significant $(\mathrm{F}=1.45 ; P=0.277)$. In field trial year two $r_{m}$ increased with each increase in fertiliser up to the $200 \mathrm{~kg} \mathrm{~N} /$ ha rate used (Table 2) from 0.191 to 0.217 , then decreased to 0.189 for the highest (250 kg N/ha) fertiliser rate, but as with year one, no differences, including the observed decrease, were significant $(\mathrm{F}=2.11 ; P=0.143)$. With the glasshouse experiment $r_{m}$ increased with each increase 
in fertiliser up to the $180 \mathrm{~kg} \mathrm{~N} /$ ha rate (Table 3), from 0.179 to 0.203 and decreased to 0.197 for the $240 \mathrm{~kg} \mathrm{~N} / \mathrm{ha}$ rate. For these results, differences were significant between the 0 fertiliser rate and the 180 and $240 \mathrm{~kg} \mathrm{~N} /$ ha rates $(\mathrm{F}=6.15 ; P<0.01)$, but the observed decrease for the highest rate was not significant.

\subsection{Grain or Whole Plant Nitrogen Content}

Analysis of the nitrogen content of the harvested grain from the field plots in both years showed there to be increases with every increase in fertiliser applied, ranging from $1.36 \%$ to $1.78 \%$ in field trial year one (Table 1) and $1.35 \%$ to $2.30 \%$ in field trial year two (Table 2). Similar results occurred with the nitrogen content of whole plants from the glasshouse experiment (Table 3), with increases ranging from $0.81 \%$ to $1.44 \%$. Several of these increases were significant: in field trial year one between the 75 and the 150 and $175 \mathrm{~kg} \mathrm{~N} /$ ha rates $(\mathrm{F}=10.91, P<0.01)$; in field trial year two between the $50 \mathrm{~kg} \mathrm{~N} / \mathrm{ha}$ rate and all of the other rates $(\mathrm{F}=0.21, P<0.001)$; and with the glasshouse experiment between the $0 \mathrm{~kg} \mathrm{~N} / \mathrm{ha}$ rate and all the other rates $(\mathrm{F}=32.72, P<0.001)$.

\section{Discussion and Conclusion}

These experiments were designed to assess how varying levels of nitrogen fertiliser applied to winter wheat, a common host plant of $M$. dirhodum, affected the performance of this aphid species. The measured nitrogen content of the experimental plants demonstrated the level of $\mathrm{N}$ assimilation; in all cases, every increase in fertiliser applied led to an increase in either grain or whole plant nitrogen content. Such effects have been well documented for cereal grains [52-54], and grain nitrogen levels correlate closely with levels of the nutrient in the flag leaf [55] on which the aphids were feeding.

Longevity was not influenced by level of fertilisation, but aphids reared in the glasshouse lived longer than those reared in the field. This was to be expected as environmental conditions in the glasshouse were maintained within narrow limits, whereas aphids in the field would have been subjected to greater fluctuations in temperature, humidity, wind and light and these conditions - especially temperature, which has a major effect on aphid development [7] — would have had an influence.

The major effect of the nitrogen applications was on aphid fecundity. At the rates of fertilisation used in the field trail in year one fecundity increased with each increase in rate used, but when rates were increased in the field trial year two and in the glasshouse, this had the effect of reducing fecundity at the highest rates of fertilisation. Although the results for intrinsic rate of increase followed a similar pattern, for this measure the reduction was not significant. In the first year in the field, fecundity increased with every increase in the amount of fertiliser applied. The reason none of these increases was significant was probably due to the narrow range of fertiliser rates used, and the relatively small increase of $25 \mathrm{~kg} \mathrm{~N}$ per treatment up to the top rate of $175 \mathrm{~kg} \mathrm{~N} / \mathrm{ha}$. The second year's field experiment was designed with a wider range of rates up to $250 \mathrm{~kg} N /$ ha and a larger increase of $50 \mathrm{~kg} \mathrm{~N}$ per treatment, to examine whether these rates would result in significant differences in performance. The glasshouse experiment was also undertaken in year two to complement the field work, with the increase of $60 \mathrm{~kg} \mathrm{~N}$ per treatment also greater than that used in the first year's field study. In the second year the decrease in fecundity for the field-caged aphids was significant, and the fact that it was not significant for the glasshouse experiment may have been because the top rate used 
then (240 kg N/ha compared with $250 \mathrm{~kg} \mathrm{~N} / \mathrm{ha}$ in the field) was not enough to elicit this response. Additionally, the growth characteristics of hydroponically-produced glasshouse plants may not be comparable to plants grown in the field [56]. However, the fact that the fecundity of the glasshouse-reared aphids followed a similar trend to those reared in the field served to underline the validity of the latter results.

There were some differences in reproductive performance between each experiment and these may be attributed to differences in growing conditions, besides temperature already mentioned. Both of the field studies were carried out in a second wheat crop on a commercial farm and, although the soil types in both fields were similar, their nutrient profiles and therefore the nutrients acquired by the plants, would not have been identical; other conditions experienced by the aphids would also have differed each year. Some differences may have been due to the age of plants when aphids were installed in the cages (between GS 60 and GS 64). This will have had some effect [14,24], but as about 90\% of the nitrogen acquired by wheat plants occurs by the end of flowering [57] and all aphids had been installed by this time, any such effects were probably negligible.

The main and unforeseen finding of a decrease in fecundity at the highest rate of fertilisation cannot readily be explained in terms of the plant or environmental influences discussed above and it demonstrates a hitherto undocumented result for this aphid species. Fecundity in herbivorous insects is determined to a large extent by the phloem sap quality of the host plants [44] and a number of studies have demonstrated how applied nitrogen affects aphid population development and reproductive performance. Recent studies have used EPG assessments, and improved stylectomy techniques have enabled pure phloem sap to be obtained; several have demonstrated that nitrogen fertiliser applications increase phloem sap amino acid concentrations. Research with the cereal aphid Rhopalosiphum padi maintained in clip cages on hydroponically grown barley seedlings with $8 \mathrm{mM} \mathrm{NH} \mathrm{NO}_{3}$ or without nitrogen [30], found that the $\mathrm{N}$-deficient plants had significantly lower concentrations of non-essential amino acids and the aphids reared on them had a significantly lower intrinsic rate of increase. This situation was similar to the $r_{m}$ reported here, where there was a significant difference between the 0 rate and the 180 and $240 \mathrm{~kg} \mathrm{~N} /$ ha fertiliser rates in the glasshouse experiment. In the same study [30] EPG's demonstrated that aphids on the N-deficient plants spent more time being unable to penetrate tissues and less time in phloem ingestion, suggesting that in such situations, where there are insufficient amino acids available for upgrading by symbionts and where there is no alternative food source, they must ingest what is available, even if this is below an acceptable nutritional 'threshold'. However, as a high nitrogen rate was not included in the R. padi study, it offers no explanation for the reduction in $r_{m}$ and significant drop in fecundity demonstrated here with $M$. dirhodum. Another study using four rates of nitrogen fertilisation (1, 3, 6 and $12 \mathrm{mM} \mathrm{NH}_{4} \mathrm{NO}_{3}$ ) on Tansy (Tanacetum vulgare) and two monophagous feeding aphid species (Uroleucon tanaceti and Macrosiphoniella tanacetaria) [58] also found that increasing $\mathrm{N}$ fertilisation increased the phloem sap amino acid concentration. In this work [58] choice-test studies demonstrated that the aphids preferred nitrogen-rich plants and settled more frequently and fed for longer on them, and as a result had higher reproduction and larval output.

Although the two studies described above demonstrated the effects of phloem sap amino acid quality on the performance and behaviour of the species they considered, neither had a sufficiently high level of nitrogen fertilisation which could have brought about a reduction in aphid performance, as demonstrated in this study. However, in a study with Mysus persicae on grafted one-year-old peach 
plants and five levels of nitrogen fertilisation $\left(0.05,3,6,10\right.$ and $15 \mathrm{mM} \mathrm{N}$ from $\left.\mathrm{NO}_{3}\right)$ [59], it was found that populations which had developed from initially placed apterous aphids, remained stable at the lowest $\mathrm{N}$ level, increased over time at the three intermediate levels and decreased at the highest level. Another study with populations of Aphis nerii, begun from apterae placed on milkweed (Asclepisa syriaca) and three rates of nitrogen fertiliser $\left(0,0.071\right.$ and $\left.0.143 \mathrm{~g} \mathrm{NH}_{4} \mathrm{NO}_{3}\right)$ [42], found that the highest populations were on plants with the intermediate levels of fertilisation. Here it was suggested the results supported the hypothesis that high levels of applied nitrogen increase plant $\mathrm{N}$ concentrations above an aphid threshold elemental ratio (TER) [60] such that performance is impaired, leading to a decrease in aphid population growth.

It is difficult to make direct comparisons between this study and others when so many aspects differ: rate and form of $\mathrm{N}$ applied; aphid species studied; plant species, type (monocotyledon or dicotyledon) and method of production used. In this study phloem sap composition was not established, but plant nitrogen analysis indicated that increased rates of $\mathrm{N}$ fertilisation led to increased $\mathrm{N}$ assimilation, resulting in increased $\% \mathrm{~N}$ composition in whole plant or grain tissue. The aphids were confined by clip cages to their feeding site and therefore had to ingest what was available to them and their reduced performance at the lower rates of fertilisation supports the hypothesis [30] that the phloem sap composition had fallen below a nutritional 'threshold'. In a similar manner, the reduction in fecundity at the highest rate of fertilisation supports the view [60] that an upper TER may also exist for M. dirhodum. Possible underlying physiological mechanisms to explain these effects have been highlighted in a recent review of the literature [44]; they include the influence of fertiliser-induced plant defensive compounds and effects on aphid gut symbionts.

This study also showed that the negative effects on the performance of M. dirhodum at high rates of nitrogen fertilisation occurred within the range of rates recommended for use on UK wheat crops. However, it is questionable whether such a reduction in aphid performance could justify a reduction in aphicide use, as it occurred at the upper end of recommended nitrogen application rates; therefore any reduction in total aphicide use would likely be small.

The situation pertaining to the insect-plant interactions described here is complex and underlines the need for further research, particularly into the influences of high nutrient levels.

\section{Acknowledgements}

Thanks to Jeff Bale and Nick Carter for technical advice and guidance with this work. Thanks to Writtle College, Essex for the use of their crops and facilities.

\section{References}

1. Blackman, R.L.; Eastop, V.F. Taxonomic Issues. In Aphids as Crop Pests; van Emden, H.F., Harrington, R., Eds.; CABI: Oxon, UK, 2007; pp. 1-29.

2 Dixon, A.F.G. Aphid ecology: Life cycles, polymorphism, and population regulation. Annu. Rev. Ecol. Syst. 1977, 8, 329-353.

3. George, K.S. Damage assessment aspects of cereal aphid attack in autumn- and spring-sown cereals. Ann. Appl. Biol. 1974, 77, 67-74. 
4 Vickerman, G.P.; Wratten, S.D. The biology and pest status of cereal aphids (hemiptera: Aphididae) in Europe: A review. Bull. Entomol. Res. 1979, 69, 1-32.

5. Kolbe, W. Studies on the occurrence of different aphid species as the cause of cereal yield and quality losses. Pflanzenschutz-Nachrichten Bayer 1969, 22, 171-204.

6. Dean, G.J. Aphid colonization of spring cereals. Ann. Appl. Biol. 1973, 75, 183-193.

7. Dean, G.J. The four dimensions of cereal aphids. Ann. Appl. Biol. 1974, 77, 74-78.

8. Carter, N.; McLean, I.F.G.; Watt, A.D.; Dixon, A.F.G. Cereal aphids: A case study and review. Appl. Biol. 1980, 5, 271-348.

9. Ankersmit, G.W.; Carter N. Comparison of the epidemiology of Metopolophium dirhodum and Sitobion avenae on winter wheat. Neth. J. Plant Pathol. 1981, 87, 71-81.

10. Dixon, A.F.G. Biology of Aphids; Edward Arnold: London, UK, 1978.

11. Attwood, P.J. Crop Protection Handbook-Cereals; BCPC Publications: Croydon, UK, 1985.

12. Leather, S.R. Overwintering in six arable aphid pests: A review with particular relevance to pest management. J. Appl. Entomol. 1993, 116, 217-233.

13. Wratten, S.D. The nature of the effects of the aphids Sitobion avenae and Metopolophium dirhodum on the growth of wheat. Ann. Appl. Biol. 1975, 79, 27-34.

14. Watt, A.D. The effect of cereal growth stages on the reproductive activity of Sitobion avenae and Metopolophium dirhodum. Ann. Appl. Biol. 1979, 91, 147-157.

15. Thornback, N. The Factors Determining the Abundance of Metopolophium dirhodum (WALK) the Rose Grain Aphid. Ph.D. Thesis, University of East Anglia, Norwich, UK, 1983.

16. Zadoks, J.C.; Chang, T.T.; Konzak, C.F. A decimal code for the growth stages of cereals. Weed Res. 1974, 14, 415-421.

17. Food and Rural Affairs Great Britain: Department for Environment; Great BritainWelsh Assembly; Fertiliser Advisers Certification and Training Scheme (FACTS) Welsh Assembly. Fertiliser Manual (Reference Book 209), 8th ed.; The Stationary Office: Norwich, UK, 2010.

18. Mengel, K. Nitrogen: Agricultural Productivity and Environmental Problems. In Nitrogen Metabolism of Plants, Proceedings of the Phytochemical Society of Europe, Mengel, K., Pilbeam, D.J., Eds.; Oxford University Press: Oxford, UK, 1992; pp. 1-15.

19. Honek, A. Nitrogen fertilization and abundance of the cereal aphids Metopolophium dirhodum and Sitobion avenae (homoptera: Aphididae). Zeitschrift fur Pflanzenkrankheiten und Pflanzenschutz 1991, 98, 655-660.

20. Wibberley, E.J. Cereal Husbandry; Farming Press Books: Ipswich, UK, 1989.

21. Zhou, X.; Carter, N. The effects of nitrogen and fungicide on cereal aphid population development and the consequences for the aphid-yield relationship in winter wheat. Ann. Appl. Biol. 1991, 119, 33-441.

22. Hopkins, W.G. Introduction to Plant Physiology, 2nd ed.; John Wiley and Sons: New York, NY, USA, 1999.

23. Marschner, H. Mineral Nutrition of Higher Plants, 2nd ed.; Academic Press: London, UK, 1995.

24. Dixon, A.F.G. Aphid Ecology: An Optimization Approach, 2nd ed.; Chapman and Hall: London, UK, 1998.

25. Pettersson, J.; Tjallingii, W.F.; Hardie, J. Host-Plant Selection and Feeding. In Aphids as Crop Pests, van Emden, H.F., Harrington, R., Eds.; CABI: Oxon, UK, pp. 97-113. 
26. Sandström, J.; Moran, N. How nutritionally imbalanced is phloem sap for aphids? Entomol. Exp. Appl. 1999, 9, 203-210.

27. Lough, T.J.; Lucas, W.J. Integrative plant biology: Role of phloem long-distance macromolecular trafficking. Annu. Rev. Plant Biol. 2006, 57, 203-232.

28. Dinant, S.; Bonnemain, J.-L.; Girousse, C.; Kehr, J. Phloem sap intricacy and interplay with aphid feeding. C. R. Biol. 2010, 333, 504-515.

29. Karley, A.J.; Douglas, A.E.; Parker, W.E. Amino acid composition and nutritional quality of potato leaf phloem sap for aphids. J. Exp. Biol. 2002, 205, 3009-3018.

30. Ponder, K.L.; Pritchard, J.; Harrington, R.; Bale, J.S. Difficulties in location and acceptance of phloem sap combined with reduced concentration of phloem amino acids explain lowered performance of the aphid Rhopalosiphum padi on nitrogen deficient barley (Hordeum vulgare) seedlings. Entomol. Exp. Appl. 2000, 97, 203-210.

31. Sandstrom, J.; Telang, A.; Moran, N.A. Nutritional enhancement of host plants by aphids-A comparison of three aphid species on grasses. J. Insect Physiol. 2000, 46, 33-40.

32. Gattolin, S.; Newbury, H.J.; Bale, J.S.; Tseng, H.-M.; Barrett, D.A.; Pritchard, J. A diurnal component to the variation in sieve tube amino acid content in wheat. Plant Physiol. 2008, 147, 912-921.

33. Girousse, C.; Bournoville, R.; Bonnemain, J.L. Water deficit-induced changes in concentrations in proline and some other amino acids in the phloem sap of alfalfa. Plant Physiol. 1996, 111, 109-113.

34. Srivastava, P.N. Nutritional Physiology. In Aphids: Their Biology, Natural Enemies and Control; Minks, A.K., Harrewijn, P., Eds.; Elsevier: Amsterdam, The Netherlands, 1987; Volume A, pp. 99-121.

35. Munson, M.A.; Baumann, P.; Clark, M.A.; Baumann, L.; Moran, N.A.; Voegtlin, D.J.; Campbell, B.C. Evidence for the establishment of aphid-eubacterium endosymbiosis in an ancestor of four aphid families. J. Bacteriol. 1991, 173, 6321-6324.

36. Liadouze I.; Fervay, G.; Guillaud, J.; Bonnot, G. Effect of diet on the free amino acid pools of symbiotic and aposymbiotic pea aphids, Acyrthosiphon pisum. J. Insect Physiol. 1995, 41, 33-40.

37. Douglas, A.E. Nutritional interactions in insect-microbial symbioses: Aphids and their symbiotic bacteria Buchnera. Annu. Rev. Entomol. 1998, 43, 17-37.

38. Febvay, G.; Rahbe, Y.; Rynkiewicz, M.; Guillaud, J.; Bonnot, G. Fate of dietary sucrose and neosynthesis of amino acids in the pea aphid, Acyrthosiphon pisum, reared on different diets. J. Exp. Biol. 1999, 202, 2639-2652.

39. Gash, A.F.; Carter, N.; Bale, J.S. The Influence of Nitrogen Fertiliser Applications on the Cereal Aphids Metopolophium dirhodum and Sitobion avenae. In Proceeding of the Brighton Crop Protection Conference, Brighton, UK, 18-21 November 1996; BCPC: Farnham, Surrey, UK, 1996; pp. 209-214.

40. Duffield, S.J.; Bryson, R.J.; Young, J.E.B.; Sylvester-Bradley, R.; Scott, R.K. The influence of nitrogen fertiliser on the population development of the cereal aphids Sitobion avenae (f.) and Metopolophium dirhodum (wlk.) on field grown winter wheat. Ann. Appl. Biol. 1997, 130, 13-26.

41. Febvay, G.; Bonnin, J.; Rahbe, Y.; Bournoville, R.; Delrot, S.; Bonnemain, J.L. Resistance of different lucerne cultivars to the pea aphid Acyrthosiphon-pisum-influence of phloem composition on aphid fecundity. Entomol. Exp. Appl. 1988, 48, 127-134. 
42. Zehnder, C.B.; Hunter, M.D. More is not necessarily better: The impact of limiting and excessive nutrients on herbivore population growth rates. Ecol. Entomol. 2009, 34, 535-543.

43. Jansson, R.K.; Smilowitz, Z. Influence of nitrogen on population parameters of potato insects: Abundance, population growth, and within-plant distribution of the green peach aphid, Mysus persicae (homoptera: Aphididae). Environ. Entomol. 1986, 15, 49-55.

44. Awmack, C.S.; Leather, S.R. Host plant quality and fecundity in herbivorous insects. Annu. Rev. Entomol. 2002, 47, 817-844.

45. Austin, A.B.M.; Tatchell, G.M.; Harrington, R.; Bale, J.S. A method for rearing cereal aphids in a small space. Entomol. Exp. Appl. 1991, 61, 91-93.

46. Noble, M.D. A simplified clip oage for aphid investigations. Can. Entomol. 1958, 90, 760.

47. Wyatt, I.J.; White, P.F. Simple estimation of instrinsic increase rates for aphids and tetranychid mites. J. Appl. Ecol. 1977, 14, 757-766.

48. Tottman, D.R.; Broad, H. The decimal code for the growth stages of cereals, with illustrations. Ann. Appl. Biol. 1987, 110, 441-464.

49. Hewitt, E.J. Sand and Water Culture Methods Used in the Study of Plant Nutrition; Tech. Comm. 22; Commonwealth Agricultural Bureaux, Farnham Royal: Bucks, UK, 1966.

50. Anon. The Analysis of Agricultural Materials, Ref. Book 427, 3rd ed.; HMSO: London, UK, 1986.

51. Zar, J.H. Biostatistical Analysis, 4th ed.; Prentice-Hall International: London, UK, 1999.

52. Naylor, R.E.L. The weight and nitrogen content of triticale grains as influenced by nitrogen fertiliser and chlormequat. Aspect. Appl. Biol. 1987, 15, 195-200.

53. Vaidyanathan, L.V.; Sylvester-Bradley, R.; Bloom, T.M.; Murray, A.W.A. Effects of previous cropping and applied nitrogen on grain nitrogen content in winter wheat. Aspect. Appl. Biol. 1987, 15, 227-237.

54. Smith, S.P.; Davies, W.P.; Bulman, C.; Evans, E.J. Responses of grain protein in winter wheat to nitrogen. Aspect. Appl. Biol. 1990, 25, 255-259.

55. Sylvester-Bradley, R. Prediction of grain protein concentration in East Anglian wheat crops by analysis of the nitrogen in their flag leaves. Aspect. Appl. Biol. 1990, 25, 261-265.

56. Dewar, A.M. Assessment of methods for testing varietal resistance to aphids in cereals. Ann. Appl. Biol. 1977, 87, 183-190.

57. Anon. The Wheat Growth Guide; Home Grown Cereals Authority: Warks, UK, 2008.

58. Nowak, H.; Komor, E. How aphids decide what is good for them: Experiments to test aphid feeding behaviour on Tanacetum vulgare (1.) using different nitrogen regimes. Oecologia 2010, 163, 973-984.

59. Sauge, M.H.; Grechi, I.; Poessel, J.L. Nitrogen fertilization effects on Myzus persicae aphid dynamics on peach: Vegetative growth allocation or chemical defence? Entomol. Exp. Appl. 2010, 136, 123-133.

60. Boersma, M.; Elser, J.J. Too much of a good thing: On stoichiometrically balanced diets and maximal growth. Ecology 2006, 87, 1325-1330.

(C) 2012 by the author; licensee MDPI, Basel, Switzerland. This article is an open access article distributed under the terms and conditions of the Creative Commons Attribution license (http://creativecommons.org/licenses/by/3.0/). 